\title{
Dune-associated sand fluxes at the nearshore termination of a banner sand bank (Helwick Sands, Bristol Channel)
}

DOI:

10.1016/j.csr.2014.01.003

Document Version

Accepted author manuscript

Link to publication record in Manchester Research Explorer

\section{Citation for published version (APA):}

Schmitt, T., \& Mitchell, N. C. (2014). Dune-associated sand fluxes at the nearshore termination of a banner sand bank (Helwick Sands, Bristol Channel). Continental Shelf Research, 76, 64-74.

https://doi.org/10.1016/j.csr.2014.01.003

\section{Published in:}

Continental Shelf Research

\section{Citing this paper}

Please note that where the full-text provided on Manchester Research Explorer is the Author Accepted Manuscript or Proof version this may differ from the final Published version. If citing, it is advised that you check and use the publisher's definitive version.

\section{General rights}

Copyright and moral rights for the publications made accessible in the Research Explorer are retained by the authors and/or other copyright owners and it is a condition of accessing publications that users recognise and abide by the legal requirements associated with these rights.

\section{Takedown policy}

If you believe that this document breaches copyright please refer to the University of Manchester's Takedown Procedures [http://man.ac.uk/04Y6Bo] or contact uml.scholarlycommunications@manchester.ac.uk providing relevant details, so we can investigate your claim.

\section{OPEN ACCESS}




\title{
Dune-associated sand fluxes at the nearshore termination of a
}

\section{banner sand bank (Helwick Sands, Bristol Channel)}

\author{
Thierry Schmitt ${ }^{1}$ and Neil C. Mitchell ${ }^{2}$ \\ ${ }^{1}$ Service Hydrogaphique et Océanographique de la Marine, 13 rue du Chatellier, CS \\ 92803, 29228 Brest Cedex 2, France \\ ${ }^{2}$ School of Earth, Atmospheric and Environmental Sciences, Williamson Bldg, Oxford \\ Road, Manchester, Manchester M13 9PL, UK.
}

keywords: sand wave, banner bank, multibeam sonar, tidal current transport, wave transport

This is the open-access version of this article published in Continental Shelf Research in 2014.

\begin{abstract}
$\underline{\text { Abstract }}$
Sand dunes typically migrate in opposing directions along the two sides of sand banks, reflecting a circulation driven by tidal current asymmetry, but it has been less clear how this pattern is distorted where banks intersect the coastline. The nearshore end of Helwick Sands, a banner bank in the Bristol Channel, was surveyed three times over three years, twice with a high-resolution multibeam echo-sounder. In both multibeam
\end{abstract}


surveys, an unusual geometry was found over the crest of the bank, whereby dunes connect continuously with the dunes on the flanks, despite the flank dunes migrating in opposite directions. The crestal dunes thus appear to realign rapidly. We suggest that this morphological behaviour arises here because of vigorous wave-driven transport and because surface waves propagate almost exactly parallel to the crestal dunes. Sand transported parallel to the crestal dunes ensures that efficient reconnection occurs with dunes migrating along the flanks, particularly at low tide when wave currents are more strongly felt at the bed.

Dunes were tracked between the surveys to assess the bedload transport fluxes associated with dune migration. Fluxes on the two flanks of the bank were found to be similar. The coarse-scale pattern of deposition and erosion was calculated from divergence of the fluxes using the continuity relation. That pattern differs strongly compared with the deposition/erosion pattern derived more directly from the bathymetry change between successive surveys. This implies that the dune-associated fluxes fail to represent all the sediment movements in this shallow area; significant contributions from storm wave-assisted transport, suspended load and/or sand transport during the reversed tide also probably affect transport flux besides dune-associated bedload.

\section{$\underline{\text { Introduction }}$}

Different flood and ebb currents lead to a circulation in the residual current adjacent to headlands and it was first suggested that banner banks, such as the Helwick, grow within eddies in those currents (Berthot and Pattriaratchi, 2006; Dyer and Huntley, 1999; Ferentinos and Collins, 1980; Heathershaw and Hammond, 1980; Neill et al., 2007; 
Neill and Scourse, 2009; Pingree, 1978; Yin et al., 2003) or by convergence of sand transported in transient eddies (Bastos et al., 2002; Signell and Harris, 2000). When the banks become established, the topographies of the banks themselves modify the currents and influence their further growth (Berthot and Pattriaratchi, 2006). In the northern Bristol Channel, the stronger ebb than flood currents (Uncles, 1983) have drawn out the sand banks west of the headlands (Figure 1). Although there has been interest in how banner banks initially form, there has been less work on how sand is transported adjacent to the coastline and any connection between the banks and the shore. The detailed studies that have been undertaken have mainly focused on the centres of the banner banks rather than their ends or on banks that are now detached from the coastline (Bastos et al., 2002; Neill and Scourse, 2009).

The migration of sand around shelf sand banks is primarily driven by tidal currents (Dyer and Huntley, 1999) and is reflected in the geometry of dunes, with their steep lee slopes commonly facing the direction of bedload transport. Dominant transport paths have been interpreted from the plan-view orientations of dune lee slopes (Belderson et al., 1982). From morphologic data, sand is often inferred to circulate around sand banks, driven by flood and ebb tidal currents of differing strengths on the two flanks (Harris and Collins, 1985). However, other influences also affect sand movements (Soulsby, 1997). For example, asymmetric oscillating currents generated under surface waves transport sand in the direction of wave travel. Sand is also moved during the reversed tide (i.e., opposing the normal movement over the lee slopes) and some occurs in suspension. Some transport may also occur by migration of superimposed small bedforms (mega-ripples). These transport components are not necessarily reflected 
simply in the translation of dunes, suggesting some (largely unknown) uncertainty in fluxes estimated from dune-tracking. Some of these effects are suggested by the geometry of dunes in other settings. McCave and Langhorne (1982) showed a similar configuration to that shown here of dunes connecting across a bank to dunes on its flanks. Such a configuration is explainable if there is transport across the bank's crest as well as parallel to its flanks so that the crestal dunes reconnect with the flank dunes as they migrate. Although some weakly asymmetric dunes have been found to migrate towards their stoss slopes in other repeat multibeam data (Van Landeghem et al., 2012), the data shown here mostly reveal a conventional migration towards lee slopes. A strong mobility of morphologic features has been shown previously here by Harris and Collins (1984), who recorded significant movements in 2-3 m high dunes immediately south of Helwick Sands over a week. On the other hand, sand bodies in other settings are apparently influenced to much greater depths by waves (Mitchell et al., 2012b) so wave-currents are suspected to be important here.

In this study, our primary objective was to estimate sand fluxes by tracking dunes between three sonar surveys of the nearshore end of a banner bank in the Bristol Channel, Helwick Sands (Figure 1). These data were then used to evaluate any imbalance of fluxes on opposing flanks that may hint at an exchange of sand with the coast. We also predicted overall bed elevation change between the surveys using the continuity relation. The success or failure of those predictions is used to evaluate the validity of the hypothesis that the dune-tracking method accurately predicts sand movements. With some calculations based on wave-buoy data contributed by ABP-MER Ltd and interpretation of the unusual configuration of bank-crossing dunes, we suggest that a 
major element of sand transport here arises from oscillating wave currents and breaking waves.

\section{Geological background}

The sands within the Bristol Channel were deposited during or shortly after the last glaciation, with very little supplied by modern rivers (Hamilton et al., 1979). During the Flandrian transgression at between 3 to $5 \mathrm{ka} \mathrm{BP}$, sea-level reached its present level here (Jennings et al., 1998) and the modern tidal regime became established (Stride and Belderson, 1990).

According to Britton (1978), Helwick Sands developed probably at around $5 \mathrm{ka}$ BP based on dating of material from nearby boreholes. His seismic data showed that the bank grew up to $40 \mathrm{~m}$ thick over a flat surface of Lias bedrock (Neville, 1970) and a thin (up to $2 \mathrm{~m}$ thick) remaining layer of gravel and till. A regular grid of sediment grab samples was collected around the Helwick (Haine, 2000). Those data have been made available to us by ABP-MER Ltd, revealing that the sediments are generally fine to medium $\left(0.2 \mathrm{~mm}<d_{50}<0.5 \mathrm{~mm}\right)$, well sorted to very well sorted sand in the East Helwick area (characterizations in Schmitt (2006)). The median grain sizes $\left(d_{50}\right)$ were $0.43,0.36$ and $0.35 \mathrm{~mm}$ on the south and north flanks and crest of the bank, respectively, suggesting that the threshold current of motion of sand varies little around the bank so that morphological differences can be attributed to varied physical influences, uncomplicated by grain size variations. The critical current velocity at $1 \mathrm{~m}$ above the bed $\left(U_{c r, 100}\right)$ computed as described in Miller et al. (1977) was shown by Schmitt (2006) to vary subtly from a maximum of $0.24 \mathrm{~m} \mathrm{~s}^{-1}$ on the south flank of Helwick Sands, to a more 
uniform $0.20 \mathrm{~m} \mathrm{~s}^{-1}$ on the crest and north flank.

\section{Oceanographic data}

Data were supplied to us from ABP-MER Ltd (W. Cooper, pers. comm.) from two Falmouth Scientific Instruments current/wave meters installed on the bed for nearly two months (16/6/1998 to 9/8/1998) within Helwick Passage as shown in Figure 2 (WCM1, $18 \mathrm{~m}$ depth) and on the easterly crest of the bank (WCM2, $9 \mathrm{~m}$ depth) (Haine, 2000). The current velocities recorded over 2 minutes each hour at $1 \mathrm{~m}$ above bed are summarised in Figure 3. WCM1 recorded currents alternating between flood and ebb tidal directions with a small ellipticity. Flood currents dominate (up to $0.82 \mathrm{~m} \mathrm{~s}^{-1}$ oriented $\mathrm{N} 120^{\circ} \mathrm{E}$ ) with a $0.16 \mathrm{~m} \mathrm{~s}^{-1}$ residual current computed over a complete lunar cycle (small arrow in Figure 3) oriented to $\mathrm{N} 135^{\circ} \mathrm{E}$. WCM2, in contrast, recorded generally weaker currents, probably retarded by friction over the crest of the bank. The flood and ebb currents are not collinear, probably because of momentum effects combined with local topography as suggested for data collected in other settings (Xu et al., 2008). Whereas the flood current runs primarily west to east parallel with the crest of the bank, the ebb current turns to the WNW some distance after it passes the headland. The residual current computed from WCM2 is $0.13 \mathrm{~m} \mathrm{~s}^{-1}$ towards $\mathrm{N} 128^{\circ} \mathrm{E}$.

Waves also recorded by the two meters, in 9 minute bursts every 3 hours by combined pressure sensor and vertical Doppler measurements, are shown in Figure 4. The figure shows the significant wave height $\left(H_{s}\right.$ or $1 / 3$ of the highest waves during each burst period) plotted as a vector in the direction of wave travel. The graphs illustrate the southwest to northeast propagation of waves typical of the Bristol Channel. The 
vectorally averaged propagation directions were $\mathrm{N} 84^{\circ} \mathrm{E}$ (WCM1) and $\mathrm{N} 46^{\circ} \mathrm{E}$ (WCM2), a difference due to refraction by shallower bathymetry under WCM2. The variability in wave propagation directions was small over this period (standard deviations of only $11^{\circ}$ $12^{\circ}$ ). The average propagation direction for WCM2 is almost exactly parallel with the crestal dunes. The average and maximum $H_{s}$ for the WCM2 record are $1.2 \mathrm{~m}$ and $3.4 \mathrm{~m}$, respectively, whereas the period average and maximum are $6.0 \mathrm{~s}$ and $9.8 \mathrm{~s}$, respectively. From linear wave theory for free surface waves (Masselink and Hughes, 2003), the $1.2 \mathrm{~m}$ and $6.0 \mathrm{~s}$ values (average conditions) imply average orbital current velocities $U_{w}$ of 0.21 $\mathrm{m} \mathrm{s}^{-1}$, whereas the $3.4 \mathrm{~m}$ and $9.8 \mathrm{~s}$ values (maximum conditions) imply $U_{w}$ of $0.73 \mathrm{~m} \mathrm{~s}^{-1}$. These values are significant compared with the tidal current velocities (Figure 3) and suggest a strong influence of wave currents over the crest of the bank. A more detailed analysis of the data (Schmitt, 2006) suggested that the magnitudes of wave currents exceeded those of tidal currents $24 \%$ and $50 \%$ of the time at WCM1 and WCM2, respectively. These do not represent the most extreme winter storm conditions, however, so even higher extreme wave-current velocities can be anticipated.

\section{Method for estimating dune-associated bedload fluxes}

The following theory for deriving bedload sand flux from bedform tracking is based on work by Crickmore (1970) and Engel and Lau (1980). If all sediment deposition and erosion occurs from bedload transport alone and reflected in dune migration, the specific sand volumetric flux $Q_{b v f}$ is related to changes in the bed elevation $z$ by the continuity relation:

$$
\frac{\partial Q_{b v f}}{\partial x}+\frac{\partial z}{\partial t}=0
$$


where $x$ is horizontal distance and $t$ is time. Equation (1) represents how an increase in $Q_{b v f}$ (positive $\partial Q_{b v f} / \partial x$ ) implies erosion (negative $\partial z / \partial t$ ). Where dunes migrate without changing shape, the bathymetry follows a kinematic wave equation:

$$
\frac{\partial z}{\partial t}=-c \frac{\partial z}{\partial x}
$$

where $c$ is the bedform celerity or migration velocity. Equations (1) and (2) can be combined to give:

$$
\frac{\partial Q_{b v f}}{\partial x}=c \frac{\partial z}{\partial x}
$$

Equation (3) can be integrated supposing that no downstream bedload movement occurs below a depth $z_{0}$ :

$$
Q_{b v f}(x)=c\left(z(x)-z_{0}\right)
$$

Over river bedforms, flow detaches at the crest and reattaches in the lower stoss slope of the next bedform (Bridge, 2003). As downstream bedform movements occur only downstream of reattachment, $z_{0}$ is taken as the elevation of the flow reattachment point. However, flow over tidal dunes with low aspect ratios, such as those measured here, is not expected to detach from the bed (Németh et al., 2007), so $z_{0}$ equals the elevation of the bedform troughs. Over a whole bedform wavelength, the average flux is:

$$
Q_{b v f}=\frac{c}{L} \int_{0}^{w}(z(x)-z 0) d x
$$

The specific volume of the dune $V_{b f}$, (the dune's cross-sectional area) is

$$
V_{b f}=\int_{0}^{L}\left(z(x)-z_{0}\right) d x
$$

where the depth $z_{0}$ is taken as the depth of the bedform troughs. Thus, equation (5) simplifies to: 


$$
Q_{b v f}=\frac{c}{L} V_{b f}
$$

which is alternatively written:

$$
Q_{b v f}=f c H
$$

where $f$ is call the bedform shape factor:

$$
f=\frac{V_{b f}}{H L}
$$

For an idealised triangular-shaped cross-section of a bedform, $f$ equals 0.5 but more usually values of around 0.6 have been used, also for subtidal dunes (Van den Berg, 1987). If bedload does not approach zero in the troughs, a further correction factor can be incorporated. Although such a correction has been shown to have a minor role in other settings (Hoekstra et al., 2004), the results below suggest this factor may be more important here.

Many of the dunes described below have rounded "cat back" profiles. Such dunes probably change profile shapes rapidly (Berné, 1993), so they are not well tracked using their crestlines. Instead, the centre of mass of each dune was derived by idealising each dune as a triangle connecting the adjacent troughs and crest after detrending the data by removing a surface fitted to the troughs (Schmitt et al., 2007), and the displacements of those centres of mass was used to estimate the dune celerities $(c)$.

Some transport may occur in suspension, which Mohrig and Smith (1996) assessed from whether particles re-spuspended at a bedform crestline can be expected to fall beyond the reattachment point at the down-stream stoss slope. Although flow separation is not expected for these low gradients, the Mohrig and Smith criterion is nonetheless useful here. A compilation of experiments by Hallermeier (1981) shows 
particles of similar densities and grain sizes to the median $0.35 \mathrm{~mm}$ sand on the crest of the bank have settling velocities of $2-6 \mathrm{~cm} \mathrm{~s}^{-1}$. Thus, for the peak currents at WCM1 of $\sim 30 \mathrm{~cm} \mathrm{~s}^{-1}$ (Figure 4), particles can be expected to fall around 3.3-10 m over the $167 \mathrm{~s}$ that the water passes a distance of $50 \mathrm{~m}$ (roughly half the dune spacing in Figure 5). Although the calculation is crude, this predicted 3.3-10 m vertical displacement is greater than the relief of the dunes so bypass of troughs by suspension is not expected to have been significant during the period of current meter observations for the median grain size. Similarly, the smaller particles probably do not bypass during fair weather conditions as the sands are well sorted. The standard deviations of $\mathrm{gs}=-\log _{2}$ (grain size in $\mathrm{mm}$ ) were found to be $0.49,0.94$ and 0.59 for the crest, north and south flanks, respectively.

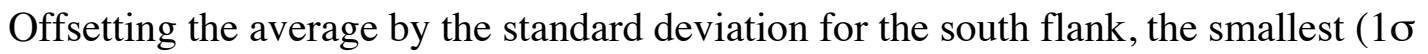
level) particles have gs $=0.3$ or $0.23 \mathrm{~mm}$. The smallest settling velocity for this grain size in the compilation of Hallermeier (1981) is $1.3 \mathrm{~cm} \mathrm{~s}^{-1}$, still implying a vertical displacement of around $2 \mathrm{~m}$. Nevertheless, these estimates relate only to fair weather conditions and significant bypass in suspension may well have occurred during winter storms.

Given the lack of information on these complicating factors, the dune-associated fluxes are estimated first in terms of the simple bedload model implied by equation (8) and the complicating factors are then assessed by testing the ability of the results to predict the bed change calculated from continuity. The figures below show the fluxes as "specific" sand transport fluxes derived from the migration rates, where "specific" fluxes refer to the mass transported per metre perpendicular to the transport direction. The values are given in terms of dry sediment mass $\left(\mathrm{kg} \mathrm{m}^{-1} \mathrm{~s}^{-1}\right)$ derived by calculating the 
volumetric flux $Q_{b v f}$ from equation (8) and multiplying by $\rho_{s}(1-\phi)$, where $\rho_{s}$ is the sand grain density and $\phi$ is deposited sand porosity (using values $\rho_{s}=2650 \mathrm{~kg} \mathrm{~m}^{-3}$ and $\phi=0.4$ recommended by Soulsby (1997)).

Method used in collecting and processing of echo-sounding data

The fieldwork and data processing are described in detail elsewhere (Mitchell et al., 2012a; Schmitt, 2006; Schmitt et al., 2007; Schmitt et al., 2008) so only a brief summary is given here. Multibeam data were collected on local workboats in September 2001 and August 2002, with single-beam data collected in May 2003. The multibeam data were collected with a 101-beam Reson Seabat $8101240 \mathrm{kHz}$ sonar, with a spatial resolution of around $1 \mathrm{~m}$ constrained here by the precision of differential Global Positioning System (GPS) broadcasts from Nash lighthouse (precision judged from the maximum mismatch of repeatedly surveyed bedrock features). An Applanix POS/MV 220 GPS-assisted motion sensor was used for attitude data. Using CARIS HIPS software, sounding data were processed by manually removing erroneous soundings (such as caused by detections of water-borne noise) and combining with sound velocity and tidal height data before gridding at $1 \mathrm{~m}$ resolution.

Data are presented as depths relative to Chart Datum (approximately Lowest Astronomical Tide). This level is dictated by the datum of the tide gauge used (at the Mumbles, $\left.51^{\circ} 34^{\prime} \mathrm{N}, 3^{\circ} 58^{\prime} \mathrm{W}\right)$. According to UK Admiralty Chart 1165 ("Bristol Channel, Worms Head to Watchet"), the reference level of the Mumbles tide gauge lies $5.00 \mathrm{~m}$ below the UK terrestrial datum (Ordinance Datum). In order to allow for variation in tidal height with position, which varies greatly in the Bristol Channel, data on tidal height 
collected in 2002 on a beach nearby to the survey allowed us to work out and apply a modest tidal phase shift and amplitude multiplier to the Mumbles gauge data to correct for variations. This procedure is explained in Schmitt et al. (2008).

Due to an erroneous setting in the motion sensor heave filter software during the 2001 survey, those data suffer from a somewhat greater noise (Schmitt et al., 2008) but are nevertheless of sufficient quality to allow dunes to be tracked between surveys. Depth differences between the 2003 single-beam and the two multibeam surveys may reflect differences in tidal height corrections (from tidal prediction software in the former and tide gauge data from an adjacent site at the Mumbles in the latter), hence we compare morphology not absolute levels between these surveys.

\section{Morphologic observations}

Figures 2 is an overview of the dataset. Helwick Sands is an east-west oriented bank rising to within $7 \mathrm{~m}$ of Chart Datum at the time of surveys. Its flanks are significantly steeper on its south than on its north side. Between East Helwick and bedrock of the coastline lies a depression to $18 \mathrm{~m}$ depth called Helwick Passage. On the north flank of East Helwick in Figure 2, dark shading on the east sides of dunes indicates that their lee slopes face to the east, whereas highlighting on the south flank shows that dune lee slopes there are oriented to the west. This reflects the expected clockwise circulation of sand around the north Bristol Channel banks (Ferentinos and Collins, 1980). These are "very large" dunes in the classification of Ashley (1990). A field of smaller dunes (but still "large dunes" in the classification of Ashley (1990)) are superimposed on them. (In the following, we use the earlier term "mega-ripple"to 
describe these smaller dunes to avoid confusion arising between very large and large dunes.) These are not tracked as they are expected to change morphology more rapidly than over one year between surveys but Figure 2 summarises their mapped extents. Such superimposed mega-ripples are present over most of the area apart from some areas of the crest of East Helwick. Previously, Schmitt et al. (2007) described how the height and spacing of the very large dunes on Helwick Sands vary. The ratio between dune height and spacing (so-called dune "steepness") tends to be smaller, especially on the crest of East Helwick, than in global datasets (Flemming, 2000), a result interpreted as due to flattening of dunes by tidal currents constricted over the bank and by surface waves.

Bedrock strata comprising Carboniferous limestone extends from Port Eynon Point, forming a contrasting lineated fabric oriented NNW-SSE on the map. At the far easterly extent of Helwick Sands adjacent to the bedrock, the dune crestlines are oriented northeast-southwest and lee slope orientations suggest transport of sand to the southeast (Schmitt et al., 2007). This marks the location where sand transported eastward along the north flank might be expected to be driven by the flood tidal currents south of, or over, the bedrock where ebb-dominated currents would return them westward, thus marking the easterly limit of the circulation.

Some dunes were associated between successive surveys from their shapes in cross-section and plan (Schmitt et al., 2007). Based on the more robust identifications, some intervening or adjacent dunes with less characteristic shapes were also identified by their context (e.g., a less characteristic dune lying between two well characterised dunes). Examples of confidently associated dunes are shown by the horizontal arrows adjacent to 
the profiles in Figure 5 (see Figure 2 for locations). Figure 6 shows the displacement field in plan view.

In Figure 5, dunes of the north flank migrated eastwards as expected between the surveys. The dunes migrated largely without changing forms greatly and without many new dunes forming between the previously existing dunes. On the south flank, dunes migrated to the west. Dunes along the west of line 1 of Figure 5 show the rounded "cat back" profiles mentioned earlier, suggested to form over strongly reversing currents (Berné, 1993). Of a subset of 11 dunes near the bank crest (Schmitt et al., 2007), 8 migrated with a change in volume of less than $25 \%$. The simple displacements of many of the dune profiles on the flanks imply that dunes migrated there primarily by bedload transport (Van den Berg, 1987).

Over the crest of the bank (easterly end of line 2 in Figure 5), the dunes were more difficult to associate between successive surveys from their shapes in profile alone. Figure 7 shows enlargements of the data over the crest of the bank. In both years, the survey data showed dunes crossing the crest of Helwick Sands and apparently connecting with dunes on either flank, despite the flank dunes migrating in alternate directions. Across the bank crest, the dunes are oriented southwest-northeast and curve convex-east as they turn to merge with north flank dunes. Two shallow-angle fork terminations can be observed in the 2002 dataset where two crestal dunes join a single flank dune. However, the southwest joinings with the south flank dunes are less acute. If the dunes are aligned perpendicular to the mean tidal transport direction (Rubin and Hunter, 1987), the veering of dunes over the bank crest reflects how the tidal current is veered by friction but accelerates to conserve discharge with decreasing water depth over the bank crest 
(Huthnance, 1982a; Huthnance, 1982b) combined with how the instantaneous flow is deflected past the headland. However, the larger current velocities in Helwick Passage (WCM1) than the bank crest (WCM2) suggest an additional funnelling effect on the flood tide produced by the bank and the coastline.

Within the crestal region, small dunes at positions 1-3 in Figure $7 \mathrm{~b}$ formed between longer dunes during the period between the surveys. Maps of the mobile layer (Schmitt et al., 2007) suggest the crestal dunes alternately merged with, and split from, flank dunes. As these crestal dunes lie in shallow water (around $7 \mathrm{~m}$ during spring low tide and are oriented almost exactly parallel to the propagation direction of surface waves measured at WCM2 in 1998 (Figure 4b), rapid reconnection of crestal with flank dunes probably arises because of large along-dune sand fluxes driven by wave currents, in particular during low tide. This is expected to be enhanced here in particular, as wavebreaking is likely to occur in these shallow depths during storms. Dune-parallel sediment movement is also corroborated by the south-southeast to north-northwest orientation of superimposed megaripples just observable in Figure 7b, which lie sub-perpendicular to the dune crests.

In Figure 6, dunes migrated in a circular pattern around the bank as expected, although those dunes immediately adjacent to the Port Eynon Point headland (eastern edge of map) surprisingly migrated westwards rather than to the southeast as expected from their asymmetry (Schmitt et al., 2007). The crestal dunes that could be confidently associated migrated westward slightly. The pattern of migrations is not uniform on each flank, with strong spatial changes in displacements observable. 


\section{Dune-associated bedload flux results}

Figure 8 shows the specific sand transport fluxes derived from the migration rates in Figure 6. The pattern is similar to that observed in Figure 6 but the scaling by dune heights $(H)$ leads to some differences. For example, on the south flank around UTM 414000 m east, large dunes imply large fluxes for a given migration rate so the duneassociated fluxes are larger on the flank than nearer to the bank crest. Similarly over the bank crest around UTM 415400 m east, large fluxes were calculated because these dunes have large heights compared with the dunes on the deeper north flank.

The mean specific transport fluxes for the north and south flanks are 0.023 and $0.026 \mathrm{~kg} \mathrm{~m}^{-1} \mathrm{~s}^{-1}$, respectively. When multiplied by the widths of the dune trains (360 and $330 \mathrm{~m}$ on north and south flanks), the total fluxes on the north and south flanks are almost equal, 8.3 and $8.6 \mathrm{~kg} \mathrm{~s}^{-1}$, respectively. There are however large gradients in bank-parallel flux. In the immediate vicinity of the headland (around UTM $415400 \mathrm{~m}$ east), there are strong gradients across the bank, varying from an eastward $0.02 \mathrm{~kg} \mathrm{~m}^{-1} \mathrm{~s}^{-1}$ near the crest to a westward $0.1 \mathrm{~kg} \mathrm{~m}^{-1} \mathrm{~s}^{-1}$ along the south flank. Farther away from the headland (e.g., around UTM 414000 m east), the gradients across the bank are less abrupt, varying from a westward $0.03 \mathrm{~kg} \mathrm{~m}^{-1} \mathrm{~s}^{-1}$ on the south to an eastward $0.03 \mathrm{~kg} \mathrm{~m}^{-1} \mathrm{~s}^{-1}$ on the north flank.

Bed level change predicted from divergence of dune-associated bedload flux

If the fluxes derived from dune migrations represent all sediment transport components, the divergence of those fluxes can be used to predict how much erosion or deposition occurs from the continuity relation (Mitchell, 2012). In two dimensions, the continuity relation is: 


$$
\frac{\partial H}{\partial t}=-\frac{\nabla \cdot Q_{b m f}}{\rho_{s}(1-\phi)}
$$

where $H$ is bed elevation and $\nabla$ is the divergence operator (Allen, 1997). As the 2001 multibeam survey covered a more limited area than the 2002 survey, we derived a bed elevation model from a more extensive single-beam dataset (Figure 9a). The calculation was carried out on a $167 \mathrm{~m}$ grid because this was the maximum dune spacing measured from the multibeam data.

Equation (10) was applied to the transport fluxes in Figure 8 after interpolating their east-west and north-south components onto a 167-m grid by triangulation (Wessel and Smith, 1991). The result in Figure 9c suggests that erosion is expected to have occurred in more areas than deposition over the bank. Some localised areas of predicted strong erosion or deposition $\left(|\partial H / \partial t|>0.6 \mathrm{~mm} \mathrm{~d}^{-1}\right)$ lie in areas lacking tracked dunes so those changes unfortunately result from poor interpolation and are undefined. Focusing, however, on the dune trains, there are some resolved areas of more modest predicted erosion and deposition that reflect where the large dune-associated fluxes in Figure 8 lie adjacent to small fluxes and thus imply spatial changes of flux.

In Figure 9b, the actual bed change is shown, derived by subtracting the 2001 single beam data (Figure 9a) from the multibeam data of 2002 (Figure 2) after averaging in $167 \mathrm{X} 167 \mathrm{~m}$ cells. The map suggests that deposition of up to $0.6 \mathrm{~mm} \mathrm{~d}^{-1}$ occurred generally across the bank crest, while erosion exceeding $0.5 \mathrm{~mm} \mathrm{~d}^{-1}$ occurred along the south flank. The pattern is less varied than that predicted from the dune-associated fluxes in Figure 9c. Figure 9d shows the difference of Figures 9b and 9c; clearly there are large errors involved in estimating bed change from spatial variations in dune-associated transport flux. 


\section{Discussion}

As not all dunes have been confidently associated between the surveys, deriving statistical levels of significance for the fluxes is difficult, but the average values suggest that there is little evidence that there was any major imbalance of sand fluxes on the two flanks between the sonar surveys, such as might be inferred if there were a strong interchange with Port Eynon Bay or with the shore to the north. Instead, on an annual basis, sand mostly circulates around the bank and any interchange is probably small relative to the flank fluxes. Although a temporary eastwards transport probably occurs during extreme winter storms (Collins et al., 1980; Harris and Collins, 1984; Pattiarathi and Collins, 1984), that transport appears not to have greatly influenced the annualised transport documented with the dune migrations (with the caviat that the dune-associated fluxes do not fully account for all sand transport as the continuity-based calculation shows).

According to the Pingree (1978) model for the development of banner banks at headlands, the region between the bank and the shore might be expected to be intensely scoured, in particular from the flood currents funnelled between the bank and the coast. Our data reveal little evidence for intense scouring, perhaps because here the wave currents also transport sand towards this area. Alternatively, if the currents are ebbdominated at the headland, momentum may leave the ebb tidal currents elevated as they flow over the headland bedrock, leaving sand somewhat protected in its lee.

If bedload transport flux were estimated purely from the tidal current (Soulsby, 1997) and if the current were uniform, dunes of differing sizes should migrate by 
differing rates. This is illustrated by equation (8), as a given sand flux $Q_{b v f}$ will migrate the dune a greater distance $c$ in unit time if the dune has small height $H$. The data, however, show some short dunes migrating at similar speeds to adjacent larger dunes, for example, at 1200-1800 $\mathrm{m}$ in profile 5 of Figure 5. Furthermore, the taller dunes exert more form drag on the overlying tidal currents than do small dunes (Hughes et al., 2008), so the tidal current itself is potentially modified by the dunes, implying an even greater speed might be expected for small dunes, in contrast to that observed. More comprehensive in-situ measurements of tidal currents are needed to investigate this.

The failure of dune-associated fluxes to represent comprehensively the sand transport may largely arise from wave-transported components. Indeed, the rapid reconnection of crestal dunes with the flank dunes (Figure 7) implies a strong wavedriven component. Although these dunes probably formed by the combined action of waves and tides, a nominal value for the along-dune flux can be obtained by assuming that each new dune volume arises solely from along-dune sand transported through the dune cross-section (e.g., through the bars marked 1-3 in Figure 7). The wave-current specific flux would then be approximately:

$$
Q_{b m f}=\frac{\rho_{s}(1-\phi) V_{c}}{W_{c} t}
$$

where $t$ is the period between surveys (328 days), $V_{c}$ is the dune volume and $W_{c}$ is its width. For dunes 1, 2 and 3 in Figure 7, the estimated $Q_{b v f}$ are $6.3,5.4$ and $2.4 \times 10^{-4} \mathrm{~kg}$ $\mathrm{m}^{-1} \mathrm{~s}^{-1}$, respectively. These values are smaller than the bank-parallel fluxes in Figure 8 . The tidal current records were also used (Schmitt, 2006) to compute the bedload flux $Q_{b m f}$ using the following formula of Gadd et al. (1978): 


$$
Q_{b m f}=\beta\left(\left|\mathbf{U}_{\mathbf{1 0 0}}\right|-U_{c r, 100)^{3}} \frac{\mathbf{U}_{100}}{\left|\mathbf{U}_{\mathbf{1 0 0}}\right|}\right.
$$

where $\boldsymbol{U}_{100}$ is the current velocity at $1 \mathrm{~m}$ above the seabed and $\boldsymbol{U}_{c r, 100}$ is the critical current velocity (bold symbols represent vectors). The parameter $\beta$ is an efficiency coefficient chosen here equal to $5.58 \times 10^{-7} \mathrm{~kg} \cdot \mathrm{s}^{2} \mathrm{~cm}^{-4}$ following Pattiaratchi and Collins (1985). The average of the calculated specific flux over one lunar cycle was $0.012 \mathrm{~kg} \mathrm{~m}^{-1} \mathrm{~s}^{-1}$ for WCM1, which compares surprisingly favourably with that derived by tracking a dune at UTM $415203 \mathrm{mE}, 5709644 \mathrm{mN}$ of $0.017 \mathrm{~kg} \mathrm{~m}^{-1} \mathrm{~s}^{-1}$. That for WCM2 was only $0.001 \mathrm{~kg}$ $\mathrm{m}^{-1} \mathrm{~s}^{-1}$, compared with $0.004 \mathrm{~kg} \mathrm{~m}^{-1} \mathrm{~s}^{-1}$ from tracking a dune at UTM $415203 \mathrm{mE}$, $5709644 \mathrm{mN}$. These values are $71 \%$ and $25 \%$ of the fluxes from dune tracking (WCM1 and $\mathrm{WCM} 2$, respectively). Thus, some transport occurs during fair weather conditions, in contrast with environments where dunes are found to be static and presumed to be active only during storms (Whitmeyer and FitzGerald, 2008). In such environments, the currents are generally below the sediment threshold of motion. Around the Helwick, the tidal currents flowing above threshold for much of the time (Figure 3) may ensure that the long-term transport is somewhat less sensitive to shear stress enhancements from occasional storm surface waves.

The combined wave- and tide-driven transport was also estimated (Schmitt, 2006) from the wave/current meter data at the bank crest site WCM2 using the method of Grant and Madsen (1986). Given that the wave data do not represent winter storm conditions, only a rough calculation was considered justified here. The calculation employed the typical tidal current $U_{100}=0.09 \mathrm{~m} \mathrm{~s}^{-1}$ during the ebb $\left(\mathrm{N} 207^{\circ} \mathrm{E}\right)$ and $U_{100}=0.175 \mathrm{~m} \mathrm{~s}^{-1}$ during the flood tide $\left(\mathrm{N} 117^{\circ} \mathrm{E}\right)$. Average waves of $H_{s}=1.17 \mathrm{~m}$ and $6.02 \mathrm{~s}$ period oriented $\mathrm{N} 047^{\circ} \mathrm{E}$ were assumed. The calculations suggested the flux should be $9 \times 10^{-4} \mathrm{~kg} \mathrm{~m}^{-1} \mathrm{~s}^{-1}$ oriented 
$\mathrm{N} 064^{\circ} \mathrm{E}$ during the flood phase and $5 \times 10^{-4} \mathrm{~kg} \mathrm{~m}^{-1} \mathrm{~s}^{-1}$ oriented $\mathrm{N} 237^{\circ} \mathrm{E}$ during the ebb

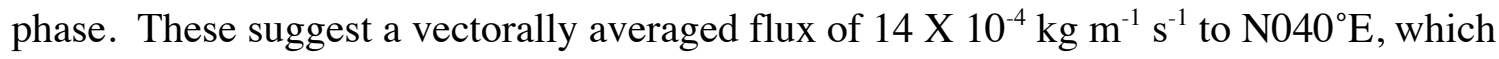
is comparable to the wave-only flux derived above from growth of dunes over the crest. The annual flux including winter storms is likely to be larger than these estimates.

We provide no test of significance of these values as they are based only on fair weather current and wave data, but they nevertheless suggest that wave-current transport is a plausible explanation for the crestal dunes. Thus the wave-effect probably induces a strong transport component parallel to the dunes over the bank crest, leading to their unusual elongation and rapid reconnection with dunes on the flanks. Wave-induced fluxes also help to explain the poor match between dune-associated changes in bathymetry and those measured directly in Figure 9. McCave and Langhorne (1982) documented megaripples (small dunes with $h=0.6 \mathrm{~m}$ ) lying between larger dunes around the end of Haisborough Sand in the southern North Sea, which imply a similar duneparallel flux.

According to Werner and Kozurek (1997), the ends of bedforms are able to migrate more rapidly than their centres because of their smaller cross-sectional areas. They likened such terminations to the defects in crystal lattices and suggested that their rapid migrations allow fields of bedforms to reorient with changing currents, fields with greater densities of defects reorienting the fastest. On the crest of East Helwick, in contrast, new defects are forced to develop by the south flank dunes migrating westwards relative to the crestal dunes. We suggest that this may have created the greater abundance of dunes observed along the south side of Figure 7b. At around $5709450 \mathrm{mN}$ along the westerly half of Figure 7b, dunes are spaced more than twice as finely as they 
are along the north side of Figure $7 b$, suggesting that they are out of equilibrium. In contrast, the two fork terminations and the more gently curved connections with the north flank dunes could have arisen from greater sand mobility where sand is temporarily depositing from wave-induced transport from the south.

\section{Conclusions}

Tidal currents dominate transport along the flanks of the bank, producing an expected clockwise circulation of dunes. North-easterly propagating surface waves however strongly affect the crest of the bank causing dunes to flatten compared with those on the flanks and induce a strong tendency for them to elongate and (unusually) to connect with dunes on the flanks, despite the flank dunes propagating in opposite directions. Although the bank-parallel fluxes derived by dune tracking are almost equal on the two flanks, suggesting that the sand movements are balanced, bed level changes predicted from dune-associated fluxes using the continuity relation do not match those found by simply differencing successive bathymetry surveys. This suggests that other forms of transport, such as from surface waves, particularly during winter storms, are important in this location.

\section{Acknowledgements}

We thank the following for providing fieldwork and equipment funding which made this project possible: the Higher Education Funding Council for Wales (NER/F/S/20/00/00146), the Royal Society, the Natural Environment Research Council (NER/E/S/2001/00408), the Countryside Council for Wales and Cardiff University. 
Mobilisation costs were also partly supported by United Utilities Green Energy Ltd., Hanson Aggregates, RMC Aggregates and United Marine Dredging. The crews of the MV New Ross 1 and Strathdoon and Mark Vincent are thanked for their work at sea and in carrying out installations. The 2003 single beam data were collected for us by Titan Environmental Surveys Ltd. We thank Longdin and Browning Ltd for help with equipment installation and measurement of tides and ABP MER Ltd (Mr. Bill Cooper) and Longdin and Browning Ltd., the British Oceanographic Data Centre for tidal current datasets. Some figures were created with the GMT software system (Wessel and Smith, 1991). We acknowledge with thanks feedback from Neil Kenyon, Mike Collins, Tony Ramsay, Richard Soulsby and two anonymous reviewers, which significantly improved this work.

\section{$\underline{\text { References }}$}

Allen, P.A., 1997. Earth Surface Processes. Blackwell, Oxford, 404 pp.

Ashley, G.M., 1990. Classification of large-scale subaqueous bedforms: a new look at an old problem. J. Sed. Petrol., 60:160-172.

Bastos, A., Kenyon, N. and Collins, M.B., 2002. Sedimentary processes, bedforms and facies, associated with a coastal headland: Portland Bill, Southern UK. Mar. Geol., 187: 235-258.

Belderson, R.H., Johnson, M.A. and Kenyon, N.H., 1982. Bedforms. In: A.H. Stride (Editor), Offshore tidal sand. Processes and deposits. Chapman and Hall Ltd., Bristol, pp. 27-55.

Berné, S., 1993. Morphology, internal structure and reversal of asymmetry of large 
subtidal dunes in the Gironde Estuary (France). J. Sed. Petrol., 63: 780-793.

Berthot, A. and Pattriaratchi, C., 2006. Mechanism for the formation of headlandassociated linear sandbanks. Cont. Shelf Res., 26: 987-1004.

Bridge, J.S., 2003. Rivers and floodplains: forms, processes and sedimentary record. Blackwell Science, Oxford, $491 \mathrm{pp}$.

Britton, R., 1978. Structure of some marine sedimentary bodies and their dynamic environments. PhD Thesis, $265 \mathrm{pp}$.

Collins, M.B, Pattriaratchi, C.B., Banner, I.T. and Ferentinos, G.K., 1980. The supply of sand to Swansea Bay. In: Collins, M.B., et al. eds. Industrialised Embayments and Their Environmental Problems: A Case Study of Swansea Bay. Oxford: Pergamon Press, 193-213.

Crickmore, M.J., 1970. Effects of flume width on bedform characteristics. J. Hydraul. Div., ASCE, 96, Proc. Paper 7077: 473-496.

Dyer, K.R. and Huntley, D.A., 1999. The origin,classification and modelling of sand banks and ridges. Cont. Shelf Res., 19: 1285-1330.

Engel, P. and Lau, Y.L., 1980. Computation of bed load using bathymetric dta. J. Hydraul. Div. ASCE, 106: 369-380.

Ferentinos, G. and Collins, M.B., 1980. Effects of shoreline irregularities on a rectilinear tidal current and their significance in sedimentation. J. Sed. Petrol., 50: 10811094.

Flemming, B.W., 2000. The role of grain size, water depth and flow velocity as scalling factors controlling the size of subaqueous dunes. In: A. Trentesaux, T. Garlan and S. Le Bot (Editors), Marine Sandwave Dynamics I, International Workshop, 
March 23-24 2000, University Lille 1, France, pp. 55-60.

Gadd, P.E., Lavelle, J.W . and Swift, D.J., 1978. Estimate of sand transport on the New York shelf using near-bottom current meter observations. J. Sed. Petrol., 48: 239252.

Grant, W.D. and Madsen, O.S., 1986. The continental-shelf bottom boundary layer. Ann. Rev. Fluid Mech., 18: 265-305.

Haine, C., 2000. Bristol Channel marine aggregates: Resources and constraints research project. Postford Duvivier and ABP MER.

Hallermeier, R.J., 1981. Terminal settling velocity of commonly occurring sand grains. Sedimentology, 28: 859-865.

Hamilton, E., Watson, P.J., Cleary, J.J. and Clifton, R.J., 1979. The geochemistry of recent sediment in the Bristol Channel - Severn Estuary System. Mar. Geol., 31: 139-182.

Harris, P.T. and Collins, M.B., 1984. Side-scan sonar investigation into temporal variation in sand wave morphology: Helwick Sands, Bristol Channel. Geo-Marine Letters, 4: 91-97.

Harris, P.T. and Collins, M.B., 1985. Bedform distributions and sediment transport paths in the Bristol Channel and Severn Estuary, U.K. Marine Geology, 62: 153-166.

Heathershaw, A.D. and Hammond, F.D.C., 1980. Secondary circulations near sand banks and in coastal embayments. Deutsche Hydrografische Zeitschrift, 33: 135-151.

Hoekstra, P., Bell, P., van Santen, P., Roode, N., Levoy, F. and Whitehouse, R., 2004. Bedform migration and bedload transport on an intertidal shoal. Cont. Shelf Res., 24: $1249-1269$. 
Hughes, M.G., Harris, P.T., Heap, A. and Hemer, M.A., 2008. Form drag is a major component of bed shear stress associated with tidal flow in the vicinity of an isolated sand bank, Torres Strait, northern Australia. Cont. Shelf Res., 28: 22032213.

Huthnance, J.M., 1982a. On one mechanism forming linear sand banks. Estuarine, Coastal and Shelf Science, 14: 79-99.

Huthnance, J.M., 1982b. On the formation of sand banks of finite extent. Estuarine, Coastal and Shelf Science, 15: 277-299.

Jennings, S.C., Orford, J.D., Canti, M., Devoy, R.J.N. and Straker, V., 1998. The role of relative sea-level rise and changing sediment supply on Holocene gravel barrier development: the example of Porlock, Somerset, UK. The Holocene, 8: 165-181.

Masselink, G. and Hughes, M.G., 2003. Introduction to coastal processes and geomorphology. Arnold, London, 354 pp.

McCave, I.N. and Langhorne, D.N., 1982. Sand waves and sediment transport around the end of a tidal sand bank. Sedimentology, 29: 95-110.

Miller, M.C., McCave, I.N. and Komar, P.D., 1977. Threshold of sediment motion under unidirectional currents. Sedimentology, 24: 507-528.

Mitchell, N.C., 2012. Modeling the rollovers of sandy clinoforms from the gravity effect on wave-agitated sand. J. Sed. Res., 82: 464-468.

Mitchell, N.C., Huthnance, J.M., Schmitt, T. and Todd, B., 2012a. Threshold of erosion of submarine bedrock landscapes by tidal currents. Earth surface processes and landforms, 38: 627-639.

Mitchell, N.C., Masselink, G., Huthnance, J.M., Fernández-Salas, L.M. and Lobo, F.J., 
2012b. Depths of modern coastal clinoforms. J. Sed. Res., 82: 469-481.

Mohrig, D. and Smith, J.D., 1996. Predicting the migration rates of subaqueous dunes. Water Resour. Res., 32: 3207-3217.

Neill, S.P., Hashemi, M. R. and Elliott, A.J., 2007. An enhanced depth-averaged tidal model for morphological studies in the presence of rotary currents. Cont. Shelf Res. 27, 82-102.

Neill, S.P. and Scourse, J.D., 2009. The formation of headland/island sandbanks. Cont. Shelf Res., 29: 2167-2177.

Németh, A.A., Hulscher, S.J.M.H. and Van Damme, R.M.J., 2007. Modelling offshore sand wave evolution. Continental Shelf Res., 27: 713-728.

Neville, G., 1970. British regional geology. South Wales. Her Majesty's Stationery Office, London, $152 \mathrm{pp}$.

Pattiaratchi, C.B. and Collins, M.B., 1984. Sand transport under waves and tidal currents: A case study from the northern Bristol Channel, UK. Marine Geol., 56: 27-40.

Pattiaratchi, C.B. and Collins, M.B., 1985. Sand transport under the combined influence of waves and tidal currents - an assessment of available formulas. Marine Geol., 67: 83-100.

Pingree, R.D., 1978. The formation of the shambles and other banks by tidal stirring of the seas. Journal of the Marine biological Association of U.K., 58: 211-226.

Rubin, D.M. and Hunter, R.E., 1987. Bedform alignment in directionally varying flows. Science, 237: 276-278.

Schmitt, T., 2006. Morphology and dynamics of headland connected sandbanks from high resolution bathymetric surveys: Helwick and Nash Sands, Bristol Channel, 
UK, Cardiff University, Cardiff, 218 pp.

Schmitt, T., Mitchell, N.C. and Ramsay, A.T.S., 2007. Use of swath bathymetry in the investigation of sand dune geometry and migration around a near shore 'banner' tidal sandbank. In: P.S. Balson and M.B. Collins (Editors), Coastal and shelf sediment transport, Geological Society Lond., Special Publication 274.

Geological Society, London, pp. 53-64.

Schmitt, T., Mitchell, N.C. and Ramsay, A.T.S., 2008. Characterizing uncertainties for quantifying bathymetry change between time-separated multibeam echo-sounder surveys. Cont. Shelf Res., 28: 1166-1176.

Signell, R.P. and Harris, C.K., 2000. Modeling sand bank formation around tidal headlands. In: A.F. Spaulding M.L. and Blumberg (Editor), Estuarine and Coastal modeling, 6th International Conference, New Orleans.

Soulsby, R., 1997. Dynamics of marine sands, a manual for practical applications. Thomas Telford Ltd., London, 249 pp.

Stride, A.H. and Belderson, R.H., 1990. A reassessment of sand transport paths in the Bristol Channel and their regional significance. Mar. Geol., 92: 227-236.

Uncles, R.J., 1983. Modelling tidal stress, circulation and mixing in the Bristol Channel as a prerequisite for ecosystem studies. Can. J. Fish. Aqua. Sci., 40 (Suppl. 1): 819.

Van den Berg, J.H., 1987. Bedform migration and bed load transport in some rivers and tidal environments. Sedimentology, 34: 681-698.

Van Landeghem, K., Baas, J., Mitchell, N.C., Wilcockson, D. and Wheeler, A., 2012. Reversal of sediment wave migration in the Irish Sea, NW Europe: A reappraisal 
of the validity of geometry-based predictive modelling and assumptions. Marine Geol., 295-298: 95-112.

Werner, B.T. and Kozurek, G., 1997. Bed-form dynamics: Does the tail wag the dog? Geology, 25: 771-774.

Wessel, P. and Smith, W.H.F., 1991. Free software helps map and display data. Eos, Transactions, American Geophysical Union, 72: 441.

Whitmeyer, S.J. and FitzGerald, D.M., 2008. Episodic dynamics of a sand wave field. Mar. Geol., 252: 24-37.

Xu, J.P., Wong, F.L., Kvitek, R., Smith, D.P. and Paull, C.K., 2008. Sandwave migration in Monterey Submarine Canyon, Central California. Marine Geol., 248: 193-212.

Yin, J., Chen, Y. and Falconer, R.A., 2003. Steady shallow-water current and solute transport around a semi-conical headland. Environmental Fluid Mechanics, 3: 221-234.

$\underline{\text { Figure captions }}$ 


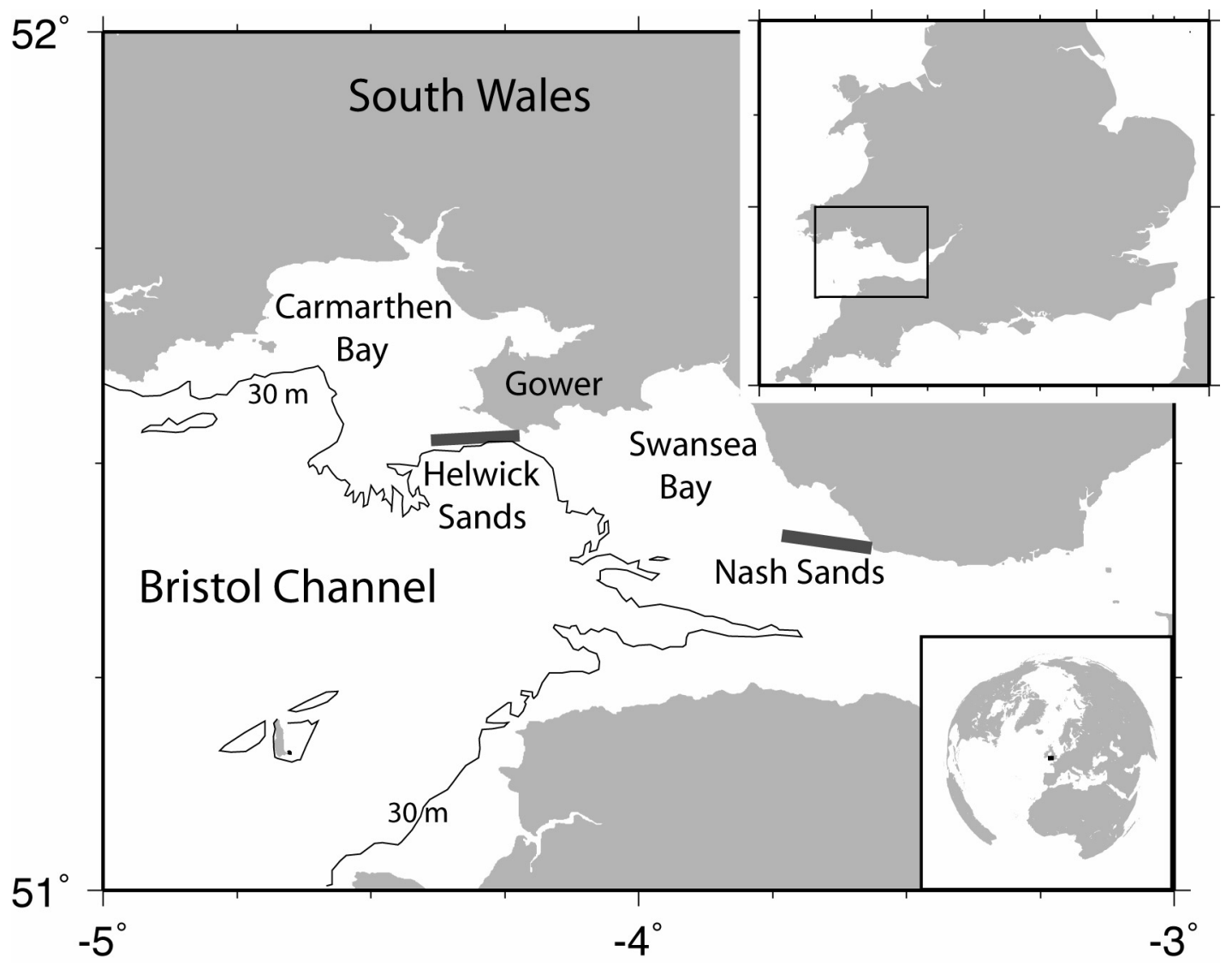

Figure 1. Location of Helwick Sands on the north side of the Bristol Channel, UK. Grey represents land. The depth contour is the $30 \mathrm{~m}$ level. 



Figure 2. (a) Map of multibeam bathymetry collected in 2002 and (b) interpretation of the easterly end of Helwick Sands, adjacent shore, Port Eynon Point bedrock and subtidal Port Eynon bay. Coordinates are in Universal Transverse Mercator (UTM) metres (zone 30, World Geodetic System (WGS) 84 ellipsoid). In (a) colour scale represents depths in metres below Chart Datum (artificial illumination is from the west) and two ' $\mathrm{X}$ '-symbols locate current meter installations. The dashed lines numbered 1-9 on this figure correspond with the profiles in Figure 5. Please see on-line article for colour version of this figure. 

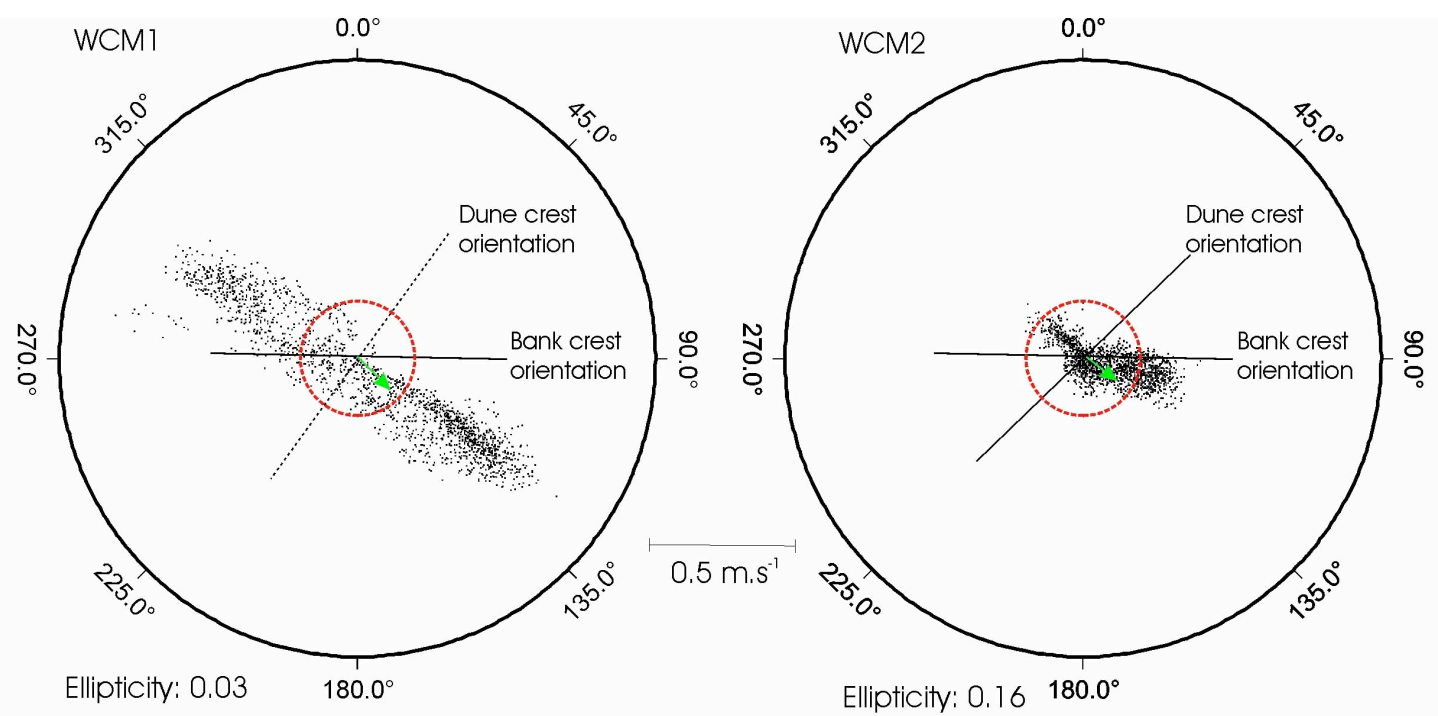

Figure 3. Tidal current data derived from two Acoustic Doppler Current Profilers

(ADCPs) installed on the bed near the easterly end of Helwick Sands for the period 16/6/1998 to 9/8/1998 (Haine, 2000). WCM1 and WCM2 were deployed in Helwick Passage and on the crest of East Helwick, respectively (located in Figure 2). Currents were derived for $1 \mathrm{~m}$ above the bed. Inner dotted circle represents the threshold of motion computed for a $0.3 \mathrm{~mm}$ diameter sand grain size. Central arrow is the residual current computed over one complete lunar cycle from the data. Bank orientation derived from data at large scale (Figure 2) and dune crest orientation from dunes adjacent to the ADCP installations. Ellipticity was calculated after fitting a major axis by regression to the data and resolving the ratio of root-mean-square distances between data points and the ellipse axes. Data courtesy of ABP-MER. Please see on-line article for colour version of this figure. 


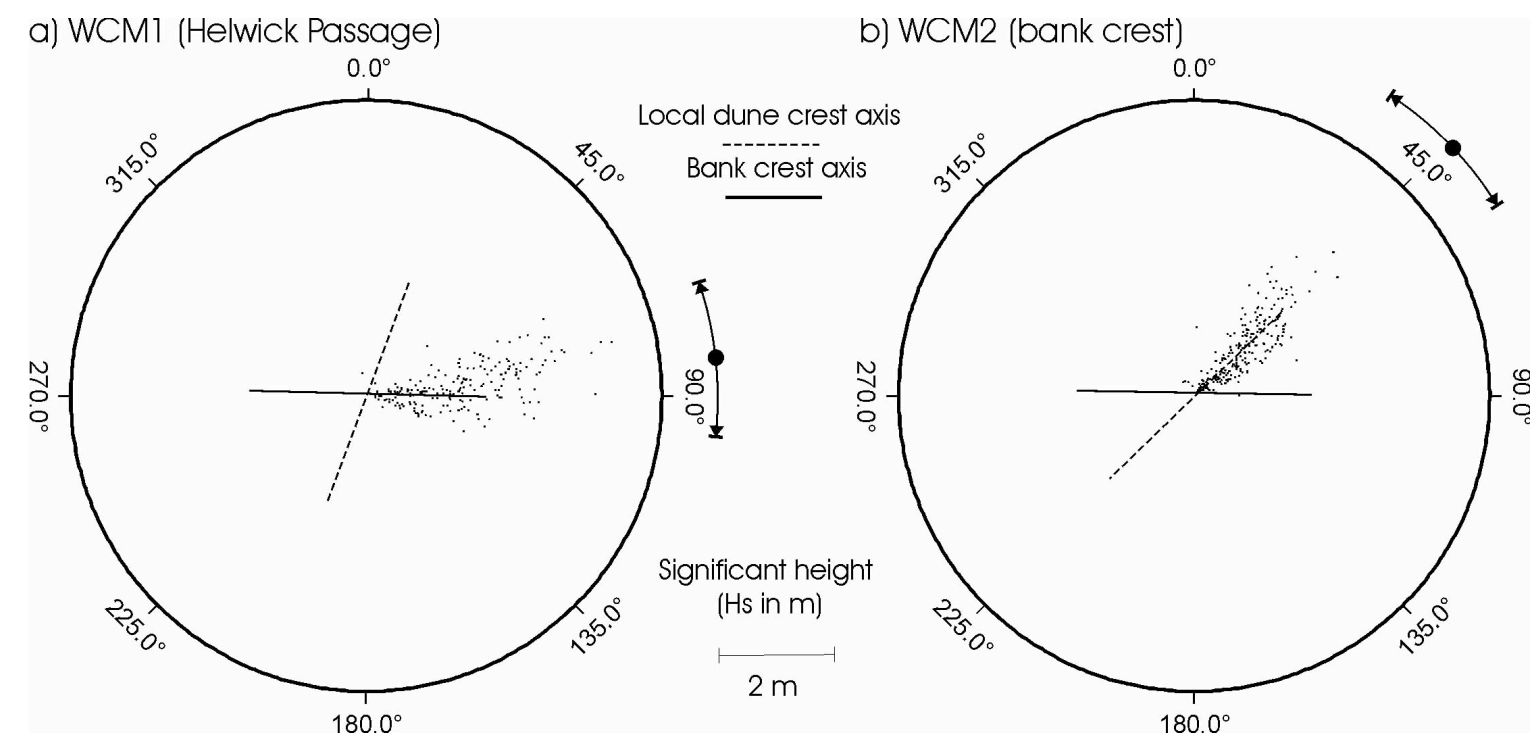

b) WCM2 (bank crest)

Figure 4. Wave data also collected with the ADCP instruments (Figure 3) (Haine, 2000).

The plots show height of the waves as distance from the centre of the plot and direction of travel. Solid dots and arrows at side of each plot are the vector average and one standard deviation of wave directions. Data courtesy of ABP-MER Ltd. 


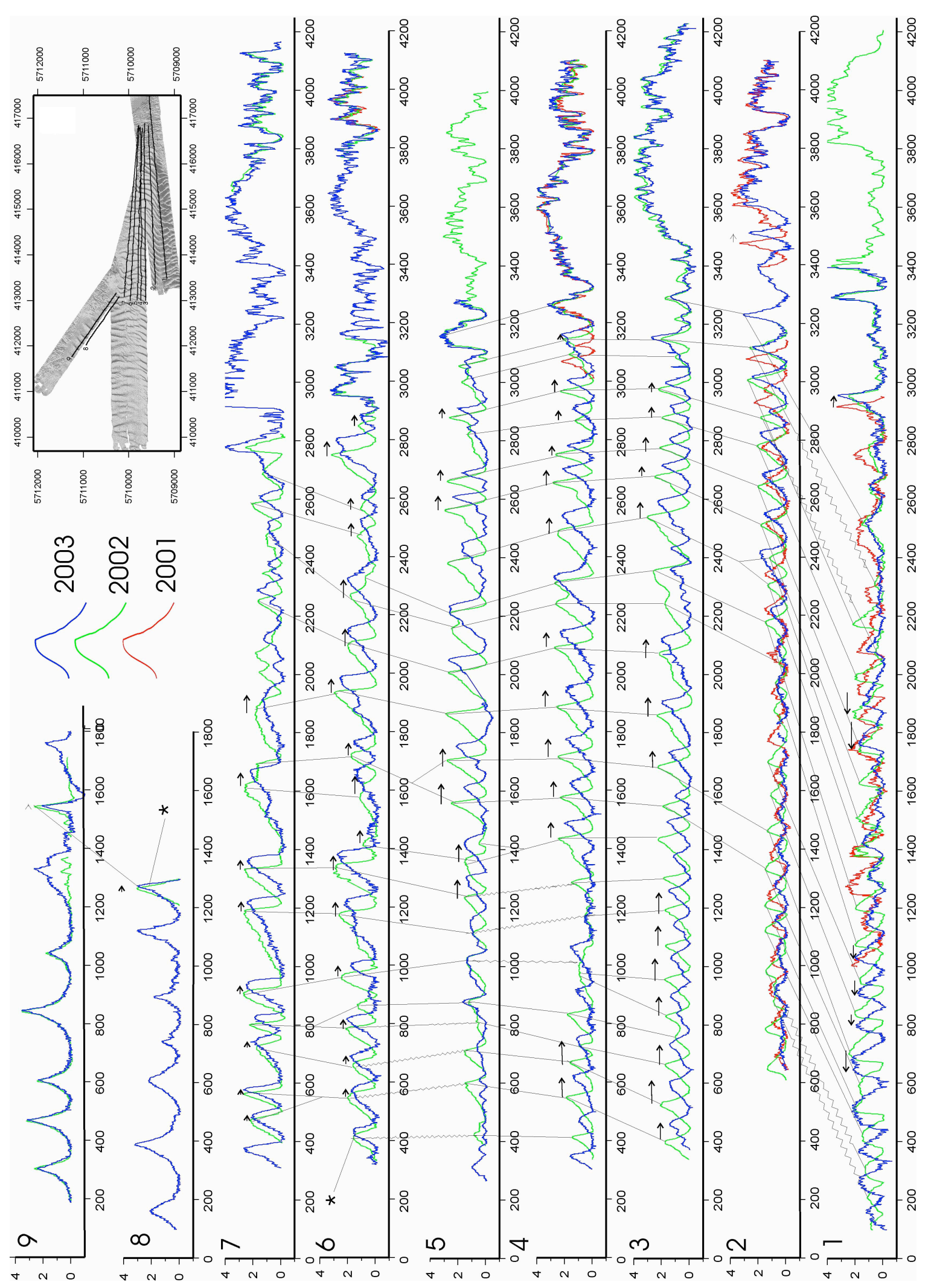


Figure 5. Profiles across the dunes derived from single-beam data collected in 2003 (blue) and sampled from the multibeam data collected in 2001 (red) and 2002 (green). The lines are located in the inset (upper-right) and in Figure 2. Profiles are in latitude order. Grey lines between profiles connect dunes continuous in plan view. Horizontal arrows mark the interpreted dune displacements between surveys. Horizontal distances are in metres along profile. Profiles have been detrended by removing a surface fitted through dune troughs (Schmitt et al., 2007) so vertical axes are altitude in metres relative to that trough surface. Please see on-line article for colour version of this figure.

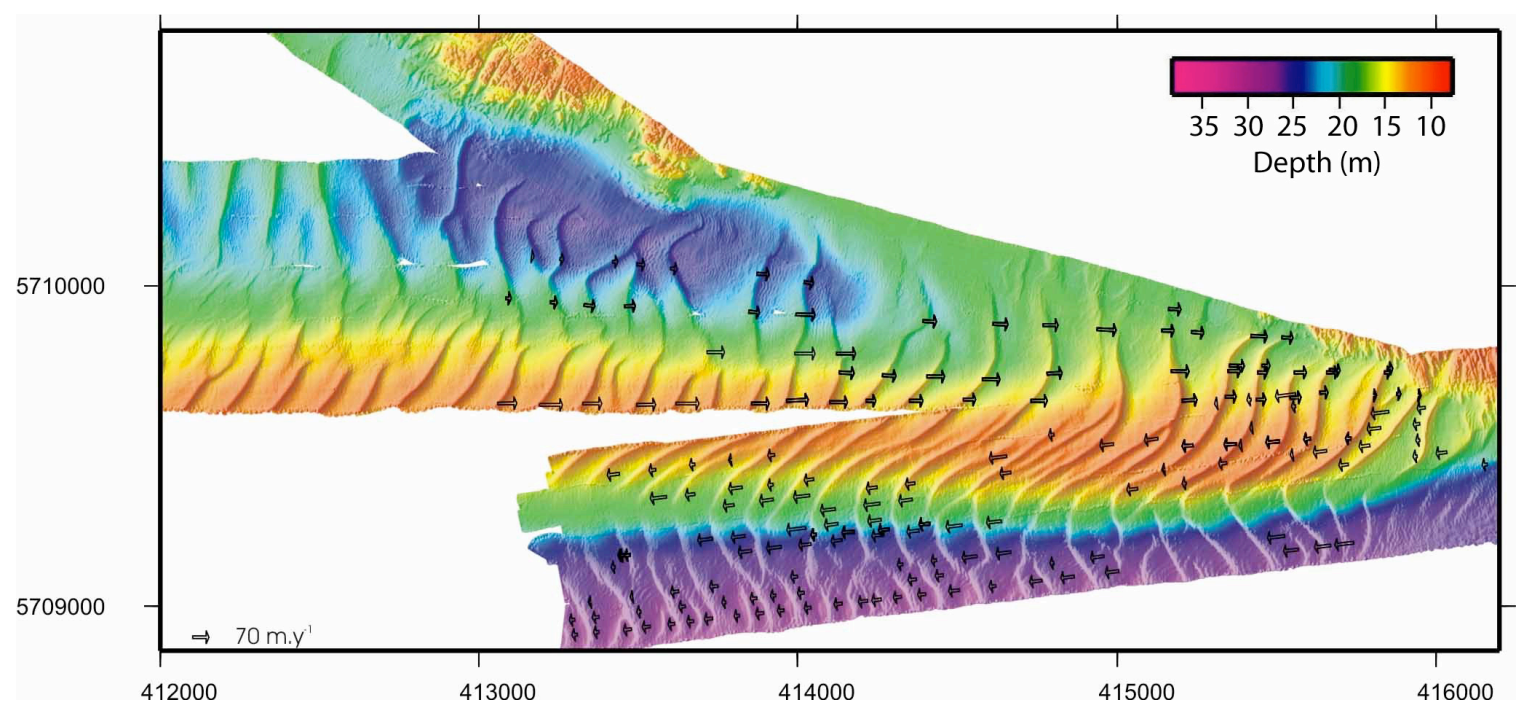

Figure 6. Map of sand displacements between years expressed as annualised migration rate (scale, lower-left) overlain on the 2002 multibeam data. Please see on-line article for colour version of this figure. 
a)

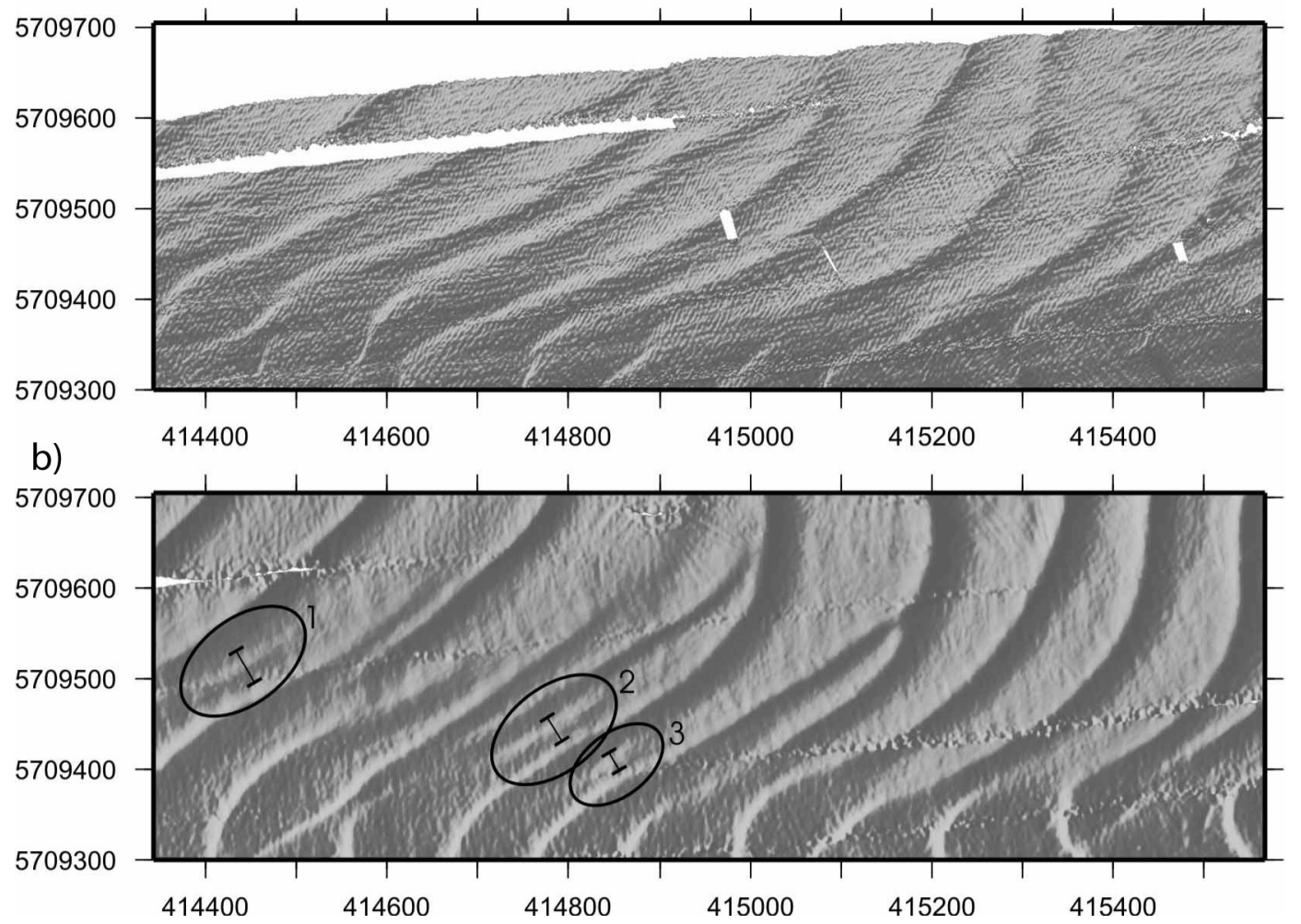

Figure 7. Shaded relief images of the multibeam bathymetry collected across the crest of Helwick in (a) 2001 and (b) 2002. Note the continuous connection of dunes on both sides of the bank across the bank's crest during both surveys. Small dunes marked 1-3 formed between the surveys are discussed in the text. 


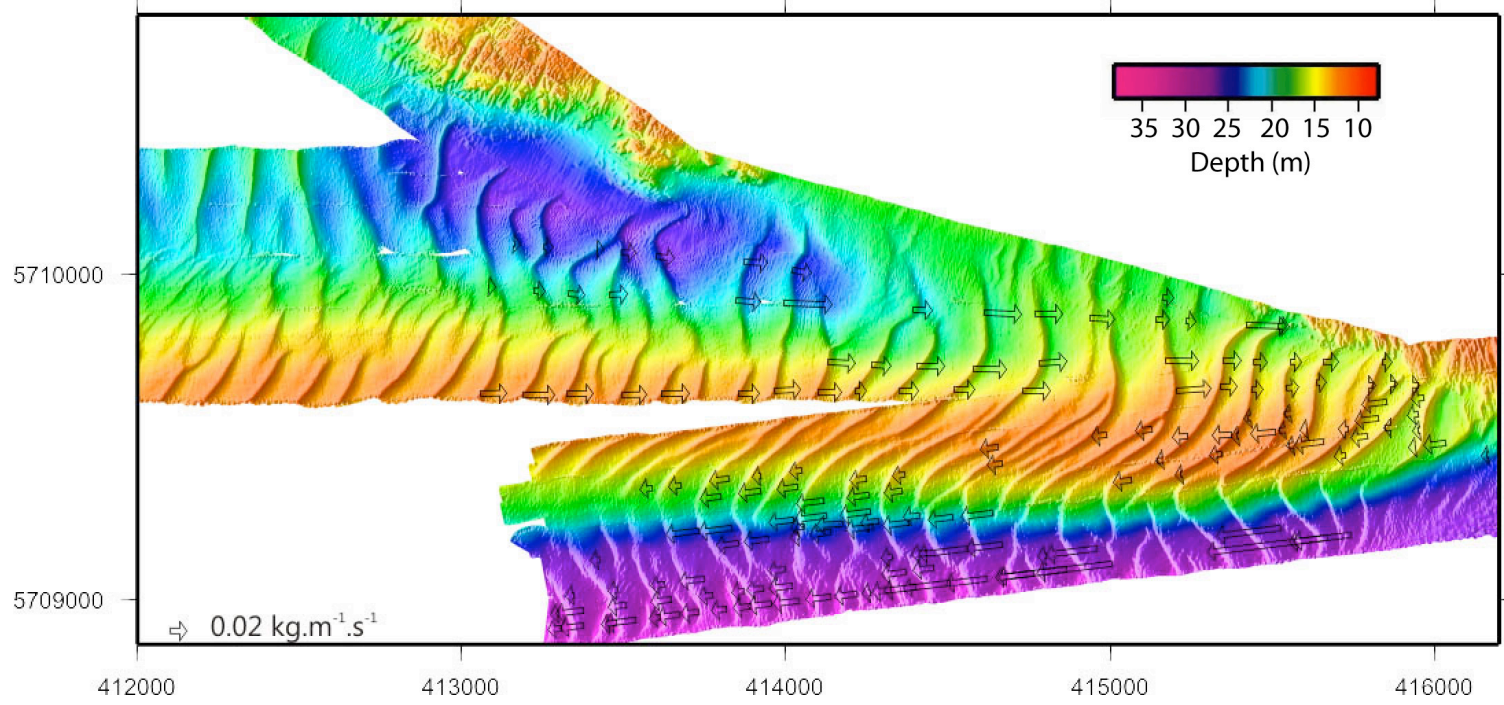

Figure 8. Map of sand specific transport flux implied by the dune displacements (scale, lower-left) overlain on the 2002 multibeam data. Please see on-line article for colour version of this figure. 
a) singlebeam survey

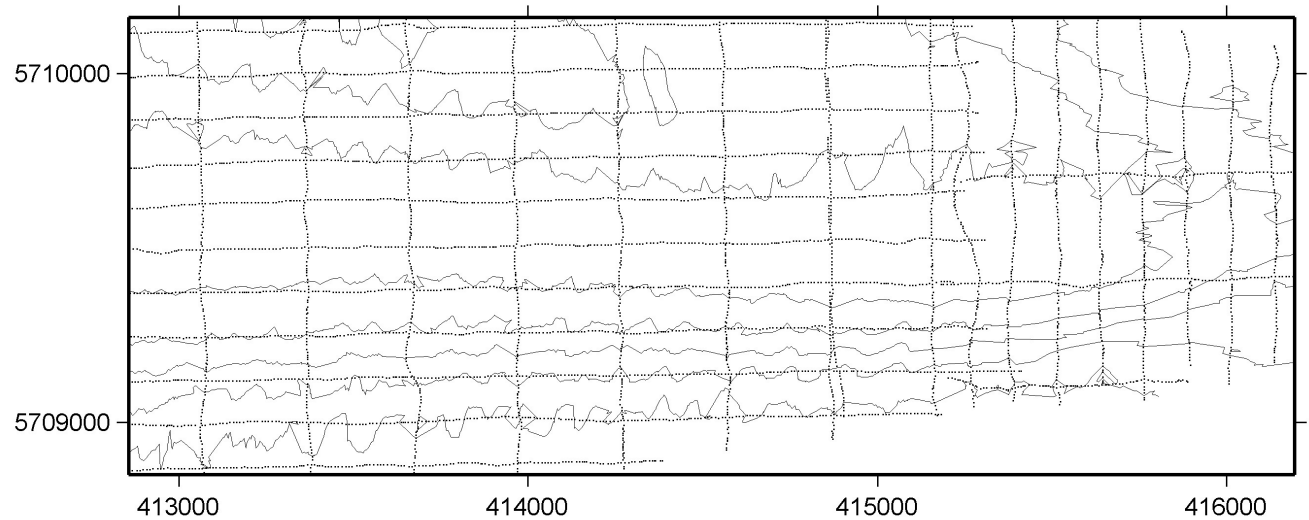

b) difference grid from the 2002 multibeam survey and the interpolated 2001 survey data (daily averaged)

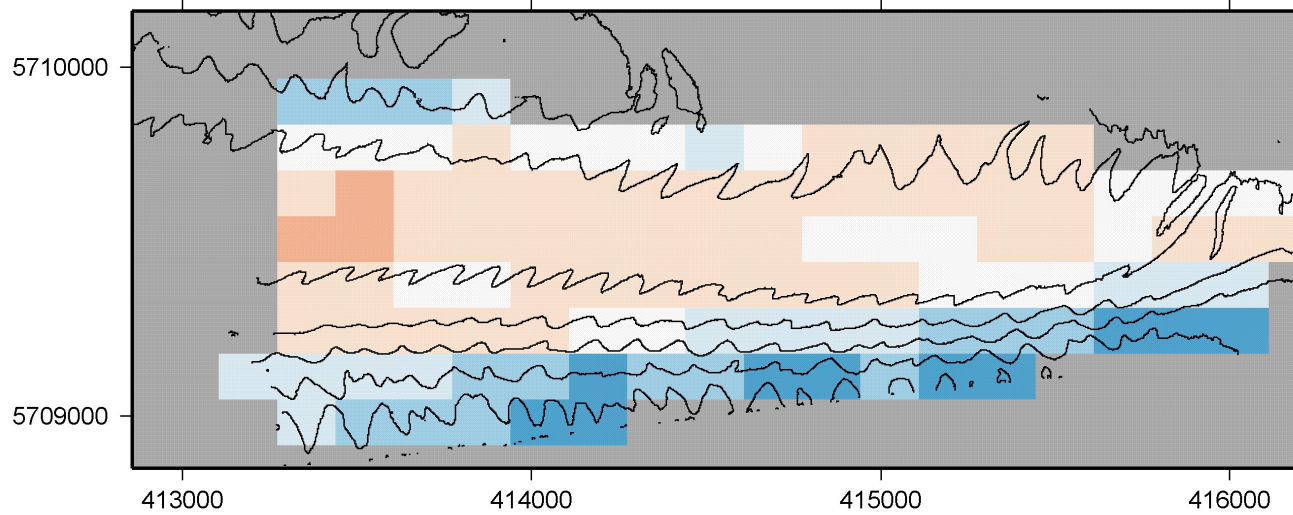

c) deposition rate derived from the sand dune flux measurement and the use of the continuity equation (daily averad

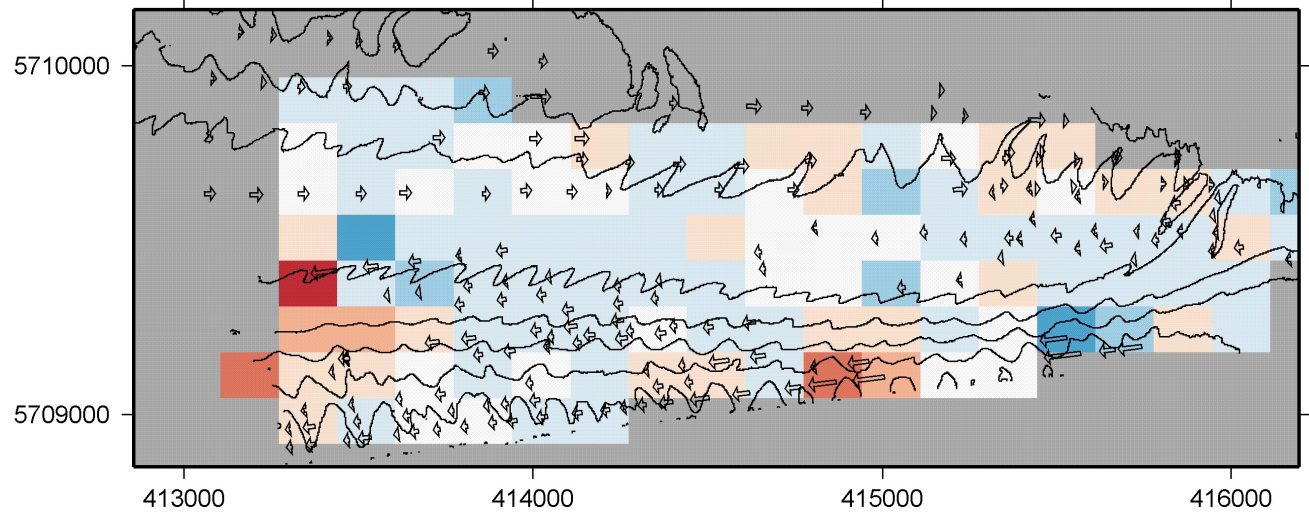

d) Residual grid between (b) and (c)

5710000

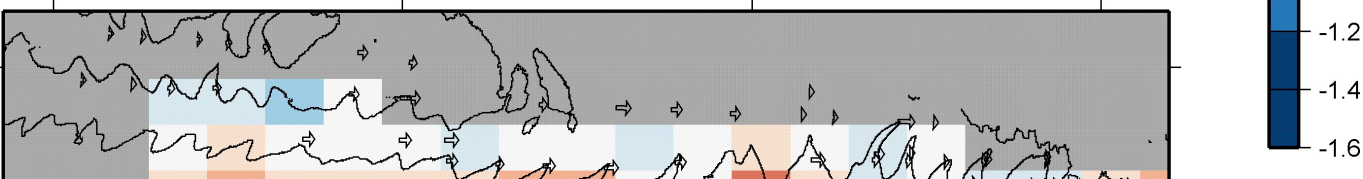

5709000

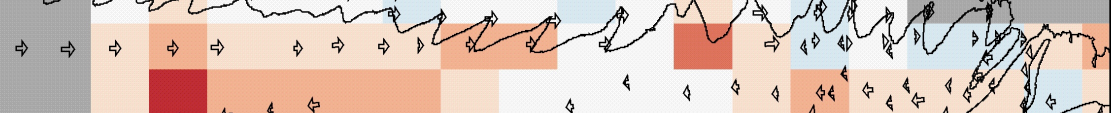

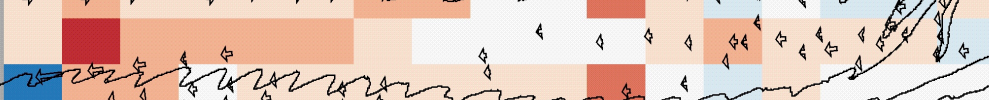

(n)

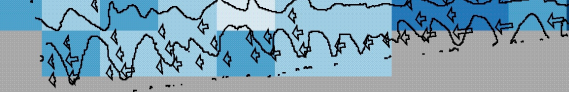

413000

414000

415000

416000 
Figure 9. Comparison of bed level changes predicted from the dune-associated transport fluxes with changes derived from two surveys. (a) Single beam bathymetry sounding lines collected in 2001 (data courtesy of Llannelli Sand Dredging Ltd.). (b) Bathymetry change between 2001 and 2002 expressed as a daily rate. Figure computed by differencing bathymetry grids produced from the 2002 multibeam and 2001 single-beam surveys interpolated onto corresponding 167-m grids. (c) Bathymetry change predicted from divergence in the dune-associated transport fluxes (Figure 8). (d) Difference of (b) and (c). Also shown on (a)-(d) are the multibeam 10-35 m contours in $5 \mathrm{~m}$ intervals. Grey areas denote missing data (grid cells around edge of multibeam are also incompletely filled with data). Please see on-line article for colour version of this figure. 